\title{
PEMBERIAN BERBAGAI DOSIS PROBIOTIK PADA PAKAN TERHADAP PERTUMBUHAN, DAN FCR IKAN BANDENG (Chanos chanos) DENGAN SISTEM POLIKULTUR
}

\author{
Tri Rahayu Ningsih ${ }^{1}$, Endah Sri Redjeki ${ }^{2}$, Sa'idah Luthfiyah $^{2}$ \\ ${ }^{1}$ Mahasiswa Program Studi Akuakultur, Fakultas Pertanian Universitas Muhammadiyah Gresik. \\ ${ }^{2}$ Dosen Fakultas Pertanian Universitas Muhammadiyah Gresik. \\ Email : Tryrahayuandrianto@gmail.com ; Phone No.+6285732098331
}

\begin{abstract}
Milkfish is including commodities that easy to cultivated and has high interest comsumption. The technology that support cultivation of milkfish still weak in optimalyze the growth of it. Research design of this study is group randomized design (RAK). The purpose of this study is to analyze the appropriate dose of growth variable, and FCR of milkfish by using policulture system. This study using 4 treatment and 3 repeatition by different probiotic dose of treatement. Treatment $\mathrm{P}_{0}$ (control), $\mathrm{P}_{1}$ (giving probiotic $8 \mathrm{ml} / \mathrm{kg}$ of feed), $\mathrm{P}_{2}$ (giving probiotic $10 \mathrm{ml} / \mathrm{kg}$ of feed), $\mathrm{P}_{3}$ (giving probiotic 12 $\mathrm{ml} / \mathrm{kg}$ of feed). Variable that observed by growth, and FCR of milkfish. The result of ANOVA analysis shows that the difference is very real of variable of daily growth rate, absolute weight, FCR of milkfish, and SGR of seaweed. Varibale that shows a difference next by BNT further testing, so that the best treatment as known is $\mathrm{P}_{2}$ (giving probiotic $10 \mathrm{ml} / \mathrm{kg}$ of feed). Giving of dose variety of feed gives real difference toward growth. Growth is indicated by daily growth rate and absolute weight. Giving $\mathrm{P}_{2}$ of probiotic (giving probiotic $10 \mathrm{ml} / \mathrm{kg}$ of feed) able to apply to cultivators so that press the value of feed conversion ratio.
\end{abstract}

Keywords: Milkfish, Growth, FCR, and Probiotic

\begin{abstract}
ABSTRAK
Ikan bandeng termasuk komoditas mudah dibudidayakan dan minat konsumsi tinggi. Teknologi budidaya ikan bandeng terbilang lambat dalam optimalkan pertumbuhan. Rancangan penelitian yang digunakan merupakan Rancangan Acak Kelompok (RAK). Penelitian bertujuan untuk menganalisis dosis yang tepat pada variabel pertumbuhan, dan FCR ikan bandeng dengan sistem polikultur. Penelitian menggunakan 4 perlakuan dan 3 ulangan dengan perlakuan dosis probiotik yang berbeda. Perlakuan $\mathrm{P}_{0}$ (kontrol), $\mathrm{P}_{1}$ (pemberian probiotik $8 \mathrm{ml} / \mathrm{kg}$ pakan), $\mathrm{P}_{2}$ (pemberian probiotik $10 \mathrm{ml} / \mathrm{kg}$ pakan), $\mathrm{P}_{3}$ (pemberian probiotik $12 \mathrm{ml} / \mathrm{kg}$ pakan). Variabel yang diamati pertumbuhan, dan FCR ikan bandeng. Hasil analisis (ANOVA) menunjukkan perbedaan sangat nyata pada variabel laju pertumbuhan harian, bobot mutlak, FCR ikan bandeng, dan SGR rumput laut melihatkan perbedaan nyata. Variabel yang menunjukkan perbedaan dilanjutkan dengan uji lanjut BNT sehingga diketahui perlakuan terbaik merupakan $\mathrm{P}_{2}$ (pemberian probiotik $10 \mathrm{ml} / \mathrm{kg}$ pakan). Pemberian berbagai dosis probiotik pada pakan perbedaan nyata terhadap pertumbuhan. Pertumbuhan yang ditunjukkan oleh laju pertumbuhan harian dan bobot mutlak. Pemberian probiotik $\mathrm{P}_{2}$ (pemberian probiotik $10 \mathrm{ml} / \mathrm{kg}$ pakan) dapat diterapkan ditingkat petambak sehingga menekan nilai rasio konversi pakan.
\end{abstract}

Kata Kunci : Ikan bandeng, Pertumbuhan, FCR, dan Probiotik 


\section{PENDAHULUAN}

Ikan bandeng merupakan salah satu komoditas dengan peminat konsumsi yang tinggi di Indonesia. Ikan bandeng memiliki peran yang cukup besar dalam peningkatan gizi masyarakat karena memiliki sifat daging yang enak serta harga terbilang terjangkau oleh masyarakat. Komoditas yang terbilang relatif mudah untuk dipelihara di kalangan masyarakat. Peminat konsumen yang tinggi, serta tahan dengan perubahan lingkungan yang ekstrim (Sudradjat, Wedjatmiko, dan Setiadharma, 2011). Terdapat beberapa faktor keunggulan sehingga banyak pihak ingin membudidayakan komoditas ikan bandeng. Perkembangan teknologi budidaya ikan bandeng di Indonesia masih dikatakan belum secepat pembudidaya udang windu. Karena ikan bandeng masih membutuhkan perkembangan teknologi dalam membudidayakan ikan bandeng agar memaksimalkan hasil produksi ikan bandeng. Perkembangan yang dibutuhkan seperti penanganan tambak yang baik, pemberian pakan yang berkualitas serta pengendalian hama penyakit (Sudrajat et al., 2011).

Sistem budidaya ikan terus berkembang mulai sistem budidaya monokultur hingga sistem budidaya polikultur. Sistem budidaya monokultur merupakan sistem budidaya satu jenis ikan atau organisme. Sedangkan sistem budidaya polikultur sistem budidaya lebih dari satu jenis ikan atau organisme. Sistem budidaya polikultur sangat efisien penggunaan pakan alami yang ada di kolam (Murachman, Nuhfil, dan Sahri, 2010). Kandungan nutrisi yang kurang lengkap dan tidak seimbang serta kemampuan ikan dalam mencerna makanan dapat menyebabkan pertumbuhan ikan menjadi lambat (Syukraini, 2012). Beberapa cara untuk meningkatkan pertumbuhan ikan salah satunya dengan menambahan enzim buatan yang menunjukkan hasil yang lebih baik (Baruah, Sahu, Pal, dan Debnath, 2004). Selain penambahan enzim pada pakan dapat juga dilakukan penambahan probiotik yang mudah dan mengguntungkan pembudidaya.

Probiotik menurut Elumalai, M. Antunes, dan Guihernio (2013) adalah mikroorganisme hidup dalam budidaya ikan yang dapat mencegah penyakit. Sehingga meningkatkan produksi dan menurunkan kerugian ekonomi. Aplikasi probiotik dalam sistem akuakultur berperan penting menentukan tingkat keberhasilan budidaya. Probiotik dikonsumsi ikan dalam jumlah cukup bermanfaat untuk kesehatan ikan. Probiotik pada bidang akuakultur memiliki efek antimikrobial untuk pengendalian patogen di saluran pencernaan. Mikroorganisme bersaing dalam saluran pencernaan mencegah patogen mengambil nutrisi yang diperlukan ikan (Cruz, Ibanez, Hermosillo dan Saad, 2012).

\section{TINJAUAN PUSTAKA}

Ikan bandeng dapat hidup pada perairan tawar (sawah atau kolam), perairan payau(tambak), perairan laut. Dikarenakan ikan bandeng termasuk jenis ikan eurihaline, jenis yang memiliki kemampuan hidup pada kadar garam dengan kisaran tinggi $0-140$ promil (Purnomowati et al., 2007). Ketika ikan bandeng mencapai dewasa, ikan akan kembali ke laut untuk berkembang biak (Purnomowati et al., 2007). Menurut sudrajat (2008) ikan bandeng memiliki pertumbuhan yang relatif cepat, yaitu $1,1-1,7 \%$ bobot badan/hari.

Probiotik secara umum dapat diartikan pro kehidupan atau pendukung kehidupan. Memiliki fungsi antara lain menunjang, mempertahankan, atau meningkatkan kehidupan ikan. Sistem kerja yang menekan atau meniadakan faktor tertentu membuat tingkat kehidupan suatu makhluk menjadi tidak kondusif. Hal ini mengakibatkan mortalitas (kematian) pada ikan meningkat (Fuller, 1992). Probiotik adalah bakteri hidup yang ditambahkan pada pakan memberi keuntungan bagi inang memperbaiki keseimbangan bakteri di dalam usus (Fuller, 1992). 
Rumput laut tidak memperlihatkan perbedaan morfologi yang dimilikinya diantara lain akar, batang, dan daun. Thallus merupakan struktur tubuh berbeda yang dimiliki tanaman ini. Ciri morfologi Gracilia sp adalah thallus yang menyerupai silinder, licin, berwarna coklat atau kuning hijau, percabangan tidak beraturan memusat di bagian pangkal dan bercabang lateral memanjang menyerupai rambut dengan ukuran panjang berkisar $15-30 \mathrm{~cm}$.

Rumput laut $G$. verrucosa termasuk Class rhodophyceae yang merupakan kelompok tumbuhan laut yang bersifat tidak bisa dibedakan antara bagian akar, batang, dan daun. Seluruh bagian tumbuhan disebut thallus, sehingga rumput laut tergolong tumbuhan tingkat rendah (Susanto dan Mucktianty, 2002). Pembudidaya dengan sistem polikultur merupakan budidaya dengan lebih dari satu jenis ikan atau organisme. Budidaya dilakukan dalam satu wada pemeliharaan. Medote budidaya polikultur merupakan salah satu sistem budidaya alternatif yang dapat mengatasi keterbatasan ruang atau wadah budidaya. Mengatasi penurunan kualitas air sehingga menyebabkan penurunan produksi ikan (Murachman, Hanani, dan Muhammad, 2010).

\section{METODOLOGI}

Dosis perlakuan probiotik EM4 dilakukan kenaikkan dan penurunan dosis pada penambahan pada pakan yakni $\mathrm{P}_{1} 8 \mathrm{ml} / \mathrm{kg}, \mathrm{P}_{2} 10 \mathrm{ml} / \mathrm{kg}, \mathrm{P}_{3} 12 \mathrm{ml} / \mathrm{kg}$, dan $\mathrm{K}$ (Kontrol) tanpa penambahan probiotik. jumlah pakan yang diberikan disesuaikan dengan biomassa ikan yang telah diketahui pada saat sampling dengan 5\%/hari dari bobot tubuh ikan. Probiotik EM4 ditambahkan dengan mencampurkan pada pakan pellet dengan cara disemprotkan menggunakan semprotan air dan ditunggu hingga kering setelah itu pakan bisa diberikan pada ikan bandeng.

Metode yang digunakan adalah metode eksperimen, dengan menggunakan rancangan percobaan yaitu Rancangan Acak Kelompok (RAK) dengan 4 perlakuan. masing-masing perlakuan diulang sebanyak 3 kali. Sehingga terdapat 12 unit perlakuan. Variabel utama yang diamati di penelitian pemberian probiotik EM4 pada ikan bandeng meliputi : pertumbuhan, dan FCR (Food Convertion Ratio). Pengamatan pertumbuhan diantara lain bobot mutlak dan laju pertumbuhan harian dilakukan pengambilan sampel ikan bandeng setiap seminggu sekali. Hasil penelitian menggunakan analisis sidik ragam (ANOVA). Jika analisi data menunjukkan perbedaan nyata maka dilanjutkan uji BNT (Beda nyata Terkecil).

\section{HASIL DAN PEMBAHASAN}

Tabel 1. Nilai Kuadrat Tengah Analisis sidik ragam (ANOVA).

\begin{tabular}{|c|c|c|c|c|c|c|c|}
\hline SK & $\mathrm{Db}$ & SGR & $\begin{array}{l}\text { Bobot } \\
\text { Mutlak }\end{array}$ & FCR & $\begin{array}{c}\text { SGR } \\
\text { Rumput } \\
\text { Laut }\end{array}$ & $\mathrm{F}_{0,05}$ & $\mathrm{~F}_{0,01}$ \\
\hline Kelompok & 2 & 0,004 & $\mathrm{O}, 178$ & 0,012 & 0,009 & 5,14 & 10,92 \\
\hline Perlakuan & 3 & $0,500 * *$ & $152,597 * *$ & $0,604 * *$ & $0,081^{*}$ & 4,76 & 9,78 \\
\hline Galat & 6 & 0,004 & 0,249 & 0,029 & 0,012 & & \\
\hline Total & 11 & & & & & & \\
\hline
\end{tabular}

Hasil analisis (ANOVA) Tabel 1 menunjukkan pada variabel kelangsungan hidup (SR) tidak menunjukkan perbedaan sangat nyata pada perlakuan dosis probiotik berbeda pada pakan sehingga tidak dilakukan uji lanjut BNT. Pada variabel laju pertumbuhan harian (SGR), rasio konversi pakan (FCR), bobot mutlak, karena terdapat perbedaan 
sangat nyata dan perbedaan nyata pada SGR Rumput laut maka variabel tersebut perlu dilakukan uji lanjut BNT.

Tabel 2. Untuk menggetahui hasil uji lanjut Beda Nyata Terkecil (BNT)

\begin{tabular}{cllll}
\hline $\begin{array}{l}\text { Perlakuan }(\mathrm{ml} / \mathrm{kg} \\
\text { pakan) }\end{array}$ & SGR & $\begin{array}{l}\text { Bobot } \\
\text { Mutlak }\end{array}$ & FCR & $\begin{array}{l}\text { SGR Rumput } \\
\text { Laut }\end{array}$ \\
\hline $\mathrm{P}_{0}$ & $2,36 \mathrm{a}$ & $25,50 \mathrm{a}$ & $1,95 \mathrm{~b}$ & $0,82 \mathrm{a}$ \\
$\mathrm{P}_{1}$ & $2,57 \mathrm{~b}$ & $28,68 \mathrm{~b}$ & $1,79 \mathrm{~b}$ & $0,86 \mathrm{a}$ \\
$\mathrm{P}_{2}$ & $3,22 \mathrm{c}$ & $40,69 \mathrm{c}$ & $1,42 \mathrm{a}$ & $1,09 \mathrm{~b}$ \\
$\mathrm{P}_{3}$ & $2,28 \mathrm{a}$ & $25,94 \mathrm{a}$ & $1,99 \mathrm{~b}$ & $0,70 \mathrm{a}$ \\
$\mathrm{BNT}_{0,05}$ & 0,12 & 1.00 & 0,14 & 0,22 \\
\hline
\end{tabular}

Keterangan :

$\mathrm{P}_{0}=$ Kontrol; $\mathrm{P}_{1}=$ pemberian probiotik $8 \mathrm{ml} / \mathrm{kg}$ pakan; $\mathrm{P}_{2}=$ pemberian probiotik $10 \mathrm{ml} / \mathrm{kg}$ pakan; $\mathrm{P}_{3}=$ pemberian probiotik $12 \mathrm{ml} / \mathrm{kg}$ pakan.

Nilai $\mathrm{BNT}_{0.05}$ digunakan nilai selisih untuk menentukan notasi. Hasil uji BNT menunjukkan perlakuan terbaik merupakan $\mathrm{P}_{2}$ (pemberian $10 \mathrm{ml} / \mathrm{kg}$ ). Pada penelitian ini dengan penambahan probiotik pada pakan memiliki perbedaan nyata pada laju pertumbuhan harian. Namun pada perlakuan $\mathrm{P}_{3}$ (Pemberian probiotik $12 \mathrm{ml} / \mathrm{kg}$ pakan) dengan penambahan probiotik dosis $12 \mathrm{ml} / \mathrm{kg}$ mengalami menurunan laju pertumbuhan harian. Hal ini menujukkan bahwa pemberian dosis yang terlalu banyak tidak baik pada sistem pencernaan ikan. kelebihan pemberian dosis probiotik tidak memberikan hasil baik pada ikan.

Tingkat efesiensi penggunaan pakan pada ikan bandeng ditentukan oleh pertumbuhan dan jumlah pakan yang diberikan. keefesienan penggunaan pakan menunjukan nilai pakan yang dapat merubah menjadi pertambahan pada berat badan ikan. Efesiensi pakan dapat dilihat dari beberapa faktor dimana salah satu diantaranya adalah rasio konversi pakan.

Pertumbuhan ikan juga dapat dipengaruhi dari kemampuan pemanfaatan pakan, misalkan pada sistem polikultur dengan kepadatan tinggi sehingga kepadatan semakin tinggi maka pemanfaatan dapat pakan menurun. kecepatan pertumbuhan ikan tergantung jumlah pakan yang dikonsumsi, kandungan protein dalam pakan. Sedangkan faktor lainnya seperti keturunan, umur, dan daya tahan serta kemampuan ikan tersebut memanfaatkan pakan.

\section{KESIMPULAN DAN SARAN}

Berdasarkan hasil penelitian tentang pemberian berbagai dosis probiotik pada pakan terhadap pertumbuhan, kelangsungan hidup, dan FCR ikan bandneg (Chanos chanos) dengan sistem polikultur dapat disimpulkan sebagai berikut : pemberian berbagai dosis probiotik pada pakan memberikan perbedaan nyata terhadap pertumbuhan, FCR ikan bandeng dan SGR rumput laut pada sistem polikultur. Perlakuan $\mathrm{P}_{2}$ (pemberian probiotik $10 \mathrm{ml} / \mathrm{kg}$ ) memberikan pertumbuhan terbaik ditunjukkan oleh laju pertumbuhan harian, bobot mutlak. FCR ikan bandeng dan SGR rumput laut juga memperlihatkan perlakuan $\mathrm{P}_{2}$ memberikan hasil terbaik. Pemberian probiotik $10 \mathrm{ml} / \mathrm{kg}$ pada pakan dapat ditingkatkan sehingga dapat menekan rasio konversi pakan. 


\section{UCAPAN TERIMAKASIH}

Pada kesempatan ini penulis mengucapkan terima kasih yang tulus kepada:

1 Ibu Ir. Endah Sri Redjeki, M.P., M.Phil. selaku Dekan Fakultas Pertanian dan selaku Pembimbing Pertama Program Universitas Muhammadiyah Gresik.

2 Dr. Andi Rahmad Rahim, S.Pi, M.Si selaku Ketua Program Studi Budidaya Perikanan Universitas Muhammadiyah Gresik.

3 Sa'idah Luthfiyah, S.Pi, M.P., selaku Dosen Pembimbing Kedua Program StudiBudiDaya PerikananUniversitas Muhammadiyah Gresik.

4 Dosen Prodi Budidaya Perikanan, Fakultas Pertanian, Universitas Muhammadiyah Gresik yang telah memberikan ilmu selama perkuliahan.

5 Teman-teman angkatan 2014 dan seluruh mahasiswa Program Studi Budi Daya Perikanan yang telah banyak membantu.

\section{DAFTAR PUSTAKA}

Baruah, K., Sahu NP, PAL AK and Debnath, D. 2004. Dietary Phytase: an Ideal Approach for a Cost Effective and Low-Polluting Aqua Feed. NAGA, World Fish Center Quarterly. 27(3\&4): 15-19.

Cruz, P. M., A.L. Ibanez, O.A.M Hermosillo and H.C.R. Saad. 2012. Use of Probiotic in Aquaculture. ISRN Microbiology.

Elumalai, M. Antunes C., Guihernio L. 2013. Effects of single metals and selected enzymes of carcinus maens Water, Air. And Soil Pollution. 141 (1-4); 273- 280.

Fuller, R. 1992. History and development of probiotics. In: Probiotics The Scientific Basis. Fuller. (Ed). Chapman \& Hall. London, New York, Tokyo, Melbourne, Madras.

Murachman, Hanani, N., \& Muhammad, S. (2010). Model Polikultur Udang Windu (Penaeus Monodon Fab), Ikan Bandeng (Chanos - Chanos Forskal) dan Rumput Laut (Gracillaris SP.) Secara Tradisional. Jurnal Pembangunan Dan Alam Lestari, $1(1)$.

Moller, H and Anders .K. 1986. Disease and parasites of marine fishes.Verlag Moller. Kiel, Germany. p: 365.

Purnomowati, I., Hidayati, D., dan Saparinto, C. 2007. Ragam Olahan Bandeng. Kanisius. Yogyakarta.

Syukraini, I. 2012. Aplikasi Penggunaan Probiotik Petrofish Dalam Pakan Gurame (Osphronemus gouramy) Pada Tahap Pendederan 5. Laporan Proyek Mandiri Polinela.

Sudradjat, A. 2008. Budidaya 23 Komoditas Laut Menguntungkan. Penebar Swadaya, Jakarta.

Susanto, A. B dan A. Mucktiany. 2002. Strategi Pengembangan Rumput Laut Pada SMK dan Community College. Pros. Seminar Riptek Kelautan Nasional.

Wedjatmiko dan Setiadharma, T. 2011. Teknologi Budidaya Ikan Bandeng. Badan Penelitian dan Pengembangan Kelautan dan Perikanan. Jakarta. 